\title{
Wicked problems i lärande för hållbar utveckling - Vägledning för att ta fram exempel och problembeskrivningar
}

\author{
Johanna Lönngren \\ Umeå universitet, Sverige
}

\begin{abstract}
Högre utbildning ska integrera hållbarhetsperspektiv, men många lärare upplever att de inte har tillräcklig kompetens eller tillgång till lämpliga pedagogiska verktyg. Ett mycket användbart pedagogiskt verktyg för lärande för hållbar utveckling är så kallade wicked problems, problem som saknar "rätta" lösningar och som karakteriseras av stor komplexitet, osäkerhet och värdekonflikter. Men för att kunna arbeta med wicked problems behöver lärare först ta fram lämpliga exempel och beskriva dessa för studenterna så att studenterna vet vad de ska arbeta med. För att underlätta för lärare att ta fram beskrivningar av wicked problems presenterar jag här åtta forskningsbaserade designprinciper och illustrerar dem med hjälp av en beskrivning av ett aktuellt problem: coronaviruspandemin. Med hjälp av dessa principer och konkreta exempel hoppas jag att fler lärare vågar ta fram egna problembeskrivningar och använda dem i sin undervisning för att på så sätt integrera hållbarhet i fler program och kurser i högre utbildning.
\end{abstract}

Nyckelord: Wicked problems, hållbarhet, scenario, rollspel, coronavirus

\section{INTRODUKTION}

Lärare i högre utbildning förväntas idag integrera hållbarhetsperspektiv i sin undervisning, men många upplever att de inte har tillräcklig kompetens eller tillgång till pedagogiska verktyg (Lönngren \& Svanström, 2015). För att underlätta för lärare har jag under drygt tio års tid arbetat med att utveckla och forska om ett pedagogiskt verktyg som har visat sig vara särskilt användbart i ingenjörsutbildningar: wicked problems.

Begreppet wicked problems myntades av designforskarna Horst Rittel and Marvin Webber (1973) som en reaktion på vad de uppfattade som ett instrumentellt och reduktionistiskt förhållningssätt till samhällsproblem. De menade att samhällsproblem på ett grundläggande sätt skiljer sig från naturvetenskapliga problem och att de därför inte kan lösas på samma sätt. Enligt Rittel och Webber är naturvetenskapliga problem tama ("tame problems"). Samhällsproblem, å andra sidan, är wicked problems som karakteriseras av en hög grad av komplexitet, osäkerhet och värdekonflikter. Det är inte möjligt att entydigt definiera ett wicked problem och det finns inga "rätt" eller "fel" lösningar — eller ens entydiga kriterier för att utvärdera hur bra en lösning är. Wicked problems är dessutom alltid unika, kontextberoende, sammanlänkade med andra problem och de kan inte "prov-lösas" eftersom varje försök att lösa ett wicked problem

*Författarkontakt: johanna.lonngren@umu.se

Artiklar och reflektioner är kollegialt granskade. Övriga bidragstyper granskas av redaktionen. Se https://hogreutbildning.se ISSN 2000-7558

(C)2021 Johanna Lönngren. This is an Open Access article distributed under the terms of the Creative Commons Attribution 4.0 International License (https://creativecommons.org/licenses/BY/4.0/), allowing third parties to share their work (copy, distribute, transmit) and to adapt it, under the condition that the authors are given credit, that the work is not used for commercial purposes, and that in the event of reuse or distribution, the terms of this license are made clear.

Citation: Lönngren, J. (2021). "Wicked problems i lärande för hållbar utveckling - Vägledning för att ta fram exempel och problembeskrivningar», Högre utbildning, 11(3), 67-75. https://doi.org/10.23865/hu.v11.3091 
får konsekvenser i samhället. Många ingenjörsutbildningar ger studenter gedigen träning i att hantera välstrukturerade och väldefinierade (tama) problem, medan wicked problems inte får mycket utrymme - trots att yrkesverksamma ingenjörer ofta arbetar med problem där både naturvetenskapliga och samhällsvetenskapliga aspekter behöver beaktas. Ny teknik utvecklas i och för en samhällelig kontext och ingenjörsstudenter behöver därför tränas att hantera wicked problems.

Även många hållbarhetsproblem beskrivs idag som wicked problems. Några exempel från litteraturen är resurshantering, styrning av fiskeri och skogsbruk, riskhantering i teknikutveckling, turismens inverkan på ursprungsbefolkningar, klimatförändringar, medborgarengagemang i samhällsutveckling, ojämlik vård, katastrofinsatser och segregering (Lönngren \& Van Poeck, 2020). För att kunna bidra till en hållbar utveckling behöver studenter få undervisning om hur den här typen av problem kan hanteras och vilka fallgropar som bör undvikas. Vi bör med andra ord undervisa våra studenter om wicked problems och hur de bör hanteras. Förväntade studieresultat för sådan undervisning kan, till exempel, vara att studenter ska lära sig vad wicked problems är, känna igen ett wicked problem när de möter ett och hantera det på ett sätt som är lämpligt för wicked problems (dessa och fler lärandemål beskrivs mer utförligt i Lönngren \& Svanström, 20I5).

Med stöd i Rittels och Webbers beskrivning (1973) kan wicked problems alltså ses som en typ av problem som är vanlig i både hållbarhets- och teknikutvecklingssammanhang. Ur ett socialkonstruktivistiskt perspektiv, å andra sidan, kan wicked problems förstås som ett retoriskt verktyg som kan användas för att uppnå olika syften (Lönngren \& Van Poeck, 2020). Ur det perspektivet ser vi att både naturvetenskapliga och samhällsvetenskapliga problem kan beskrivas som wicked - eller tama. Enligt Ison et al. (2015) bör termen wicked därför ses som ett bland flera tänkbara sätt att beskriva samma problem och att valet av hur ett problem beskrivs får följder för hur det kommer att hanteras i praktiken. Grint (2005) föreslår att när problem beskrivs som tama skapas förväntningar om att problemet liknar andra problem som har lösts tidigare och att arbetet med att lösa problemet främst handlar om att bland befintliga metoder välja en som är lämplig för det aktuella problemet (jfr undervisning där studenter får i uppgift att applicera en given algoritm). När problem beskrivs som wicked, däremot, skapas förväntningar om att problemet är unikt och komplext och att det därför inte kan lösas med befintliga metoder. Istället krävs att de som berörs av, och arbetar med, problemet tillsammans utforskar och utvecklar nya metoder (jfr undervisning där studenter lär sig att genomföra projektarbeten i samarbete med samhällsaktörer).

Ett socialkonstruktivistiskt synsätt på wicked problems innebär också att vi med relativt små medel, utan att göra omfattande förändringar, kan lyfta in hållbarhetsperspektiv i vår undervisning. Vi behöver inte nödvändigtvis ersätta de exempel och problem vi använder i vår undervisning med problem som andra har beskrivit som wicked — ibland kommer vi långt med att helt enkelt beskriva de problem vi redan undervisar om som lite mer wicked. Till exempel kan vi i statistikkurser be studenter att beräkna risker för att något ska inträffa och utifrån resultaten diskutera hur olika samhällsgrupper påverkas av den potentiella risken. Därefter kan vi be studenterna ta ställning till om de anser att risken är värd att ta i förhållande till den potentiella nyttan. Dessa diskussioner behöver inte ta upp en hel lektion, det kan ofta vara mer värdefullt att lägga in många korta diskussionstillfällen som gör studenterna uppmärksamma på att dessa diskussioner kan och bör föras som en naturlig del av ingenjörers och andra yrkesverksammas dagliga arbete. 
Undervisning som använder wicked problems som ett sätt att beskriva problem kallas här för undervisning med wicked problems för att betona att wicked problems ses som ett pedagogiskt verktyg snarare än (endast) ett innehåll. Att skifta perspektiv från undervisning om wicked problem till undervisning med wicked problems gör det möjligt att formulera nya typer av förväntade studieresultat, till exempel att lära sig att beskriva ett givet problem som ett wicked problem samt att beskriva olika tänkbara sätt att hantera problemet som är förenliga med en sådan problembeskrivning. Det kan också handla om att lära sig analysera hur olika aktörers värderingar och intressen påverkar hur aktörerna väljer att beskriva ett problem och vilka typer av lösningsförslag de lyfter fram; eller att i samarbete med andra utforska och utveckla gemensamma värderingar som kan fungera som bas för att gemensamt hantera ett wicked problem.

Ett aktuellt exempel på ett problem som kan beskrivas som ett wicked problem och lyftas in i undervisningen är coronapandemin, då det kännetecknas av stor komplexitet, osäkerhet och värdekonflikter som kan diskuteras i undervisningen. Till exempel är det mycket vi ännu inte vet om viruset, vaccinen och behandlingar mot sjukdomen. Det finns även många motstridiga intressen och värderingar, till exempel relaterade till ekonomiska effekter av restriktioner och risk för sjukdom och död orsakade av viruset. Vem ska bestämma vad som är det "rätta" sättet att hantera pandemin eller hur vi ska mäta om en viss åtgärd är "framgångsrik"? Ska vi mäta antal personer som dör, antal företag som går i konkurs eller antal sjuksköterskor som blir utmattade och lämnar yrket? Det är inte heller möjligt att använda samma åtgärder överallt eftersom kulturella värderingar, klimat, befolkningstäthet, arbetsmarknadsstruktur och många andra faktorer påverkar vilka konsekvenser vi får när vi sätter in en viss åtgärd. Den höga graden av komplexitet, motstridiga intressen och den nära kopplingen till andra problem (t.ex. arbetslöshet, brister i äldrevården, klimatförändringar) gör coronapandemin till ett lämpligt verktyg för att stimulera studenter att diskutera utifrån många olika perspektiv och öva på att hantera osäkerhet och värdekonflikter. Problemet berör i stort sett alla yrkesgrupper och kan därför användas i de flesta utbildningar — även i inter- och transdisciplinär undervisning.

\section{WICKED PROBLEMS SOM PEDAGOGISKT VERKTYG I LÄRANDE FÖR HÅLLBAR UTVECKLING}

I undervisning om och för hållbar utveckling kan wicked problems till exempel användas som underlag för att iscensätta ett rollspel där olika intressenter diskuterar och förhandlar om hur ett givet problem bör hanteras (Lönngren et al., 20IO). Ett lämpligt upplägg är att först låta studenterna förbereda sig individuellt genom att läsa en kort beskrivning av problemet och eventuellt självständigt ta reda på mer information som behövs för att kunna diskutera problemet. Sedan kan studenterna indelas i ett antal intressegrupper där varje grupp får i uppgift att förbereda sig för en diskussion om hur problemet bör hanteras — utifrån den givna gruppens perspektiv. Därefter grupperas studenter i tvärgrupper med minst en representant från varje intressegrupp. I tvärgrupperna ska studenterna först genomföra ett rollspel där de framför argument och motargument för olika lösningsförslag. Till sist kan tvärgrupperna få i uppgift att tillsammans försöka hitta en lösning som de tror alla intressegrupper skulle kunna acceptera. Tvärgrupperna kan sedan presentera sina lösningar för de andra grupperna.

För att kunna arbeta med wicked problems behöver lärare ta fram en beskrivning av ett problem som kan fungera som utgångspunkt för studenternas diskussioner, men många lärare upplever att det är svårt att ta fram sådana beskrivningar (Lönngren, 20I7). I nästa avsnitt 
kommer jag därför att presentera en vägledning för att konstruera problembeskrivningar för undervisning om och med wicked problems. Jag kommer att presentera åtta designprinciper (vidareutvecklat från Lönngren, 2017) och illustrera dem med hälp av en beskrivning av coronapandemin som ett aktuellt exempel på ett wicked problem (figur I).

I december 2019 upptäcktes ett nytt coronavirus, SARS-CoV-2, i Wuhan i Kina.

Viruset orsakar sjukdomen covid-19 och kan ge symptom som snuva, hosta, andnöd och feber. I vissa fall orsakar viruset lunginflammation, vilket kan leda till döden. Det har visat sig att dödligheten korrelerar med, bland annat, underliggande sjukdomar [FR1], ålder, socioekonomiska faktorer (inkomst, yrke, utbildning) och kön. De exakta nivåerna för dödligheten är dock fortfarande oklara. Samtidigt får många som smittas inga eller endast milda symptom, vilket gör att smitta inte alltid upptäcks.

Efter det initiala utbrottet spreds viruset snabbt inom och utanför Kina. I mars 2020 bekräftades inhemsk smittspridning i Sverige och Världshälsoorganisationen (WHO) klassade spridningen av viruset som en pandemi. De svenska myndigheterna vidtog en rad åtgärder för att begränsa smittan, såsom avrådan från icke-nödvändiga resor inom och utanför Sverige och förbud mot stora allmänna sammankomster och offentliga tillställningar. Trots åtgärderna fortsatte spridningen initialt, vilket ledde till en mycket ansträngd situation $i$ vården $[V F]$ och många dödsfall bland äldre.

Samtidigt ledde åtgärderna mot smittspridningen i både Sverige och världen till en ekonomisk kris med stora börsnedgångar, ökande arbetslöshet, fattigdom och konkurser. Besöksnäringen drabbades särskilt hårt [SRA], trots omfattande, ekonomiskt kostsamma stödpaket från regeringen [FD]. Även utbildningen påverkades då all undervisning på gymnasieskolor, universitet och högskolor ställdes om till distansundervisning. Sämre utbildning, framförallt för skolbarn, kan i sin tur $i$ framtiden fä negativa socioekonomiska och hälsomässiga effekter, speciellt för barn $i$ utsatta familjer eller barn med vissa typer av funktionsvariationer [FR2].

Under våren ledde minskat resande och industriell produktion samtidigt till tillfälligt minskade växthusutsläpp. Detta ses av vissa som en möjlighet att bromsa den globala uppvärmningen [FFS], till exempel genom att ställa om till fler digitala möten och konferenser och att använda ekonomiska stödpaket för att stimulera en grön omställning istället för att stötta industrier till att fortsätta använda fossila bränslen.

Spridningen av viruset minskade under sommaren och många restriktioner lättades tillfälligt. Men under hösten ökade spridningen igen och myndigheterna införde återigen restriktioner för resor, sammankomster och tillställningar, samt för alkoholförsäljning och öppettider för restauranger och pubar. Nu är oron stor för att smittspridningen ska hålla i sig även under julledigheten och för de effekter som både spridningen av viruset och myndigheternas åtgärder kan få. Därför bjuder Folkhälsomyndigheten nu in en rad intressenter för att diskutera och försöka enas om vilka restriktioner, rekommendationer och stödpaket som bör gälla under jul och nyår 2020.

Figur I. Förg- och typsnitts-kodad beskrivning av coronaviruspandemin för undervisning om och med wicked problems. Färgernas och typsnittens betydelse förklaras i texten. 


\section{DESIGNPRINCIPER FÖR PROBLEMBESKRIVNINGAR}

I. Välj ett problem som du tror kan engagera dina studenter. Det är lättare att skapa engagemang och bra förutsättningar för lärande för hållbar utveckling om undervisningen fokuserar på verkliga eller verklighetsnära problem (Brundiers et al., 20I0; Molderez \& Fonseca, 20I8). Coronapandemin är ett utmärkt exempel eftersom den starkt påverkar våra liv och därför engagerar de flesta. Du kan också välja ett problem som kan förväntas uppstå i framtiden, till exempel hur översvämningar orsakade av stigande havsnivåer ska hanteras eller hur naturresurser i Arktis ska bevaras eller fördelas mellan olika länder. En fördel med att välja ett framtida problem är att du har mer frihet i utformningen av problembeskrivningen, vilket gör det lättare att styra studenternas diskussioner och skapa bra förutsättningar för lärande för just dina studenter. En nackdel är att även studenterna har mer frihet att utforma sina argument. De kan till exempel hitta på fakta, vilket kan förändra dynamiken i diskussionerna på ett negativt sätt. En annan nackdel är att problemet blir mindre verkligt, vilket i sin tur kan minska studenternas engagemang och intresse. Det är också möjligt att använda ett historiskt exempel, men då finns det en risk att diskussionerna påverkas av hur problemet faktiskt hanterades och att studenterna upplever att "facit" redan finns.

2. Välj intressegrupper som skapar möjligheter att diskutera problemet utifrain olika perspektiv. Beroende på hur stor din studentgrupp är kan du välja två till sex intressegrupper. Ju fler intressegrupper du väljer, desto fler perspektiv kan du förvänta dig att studenterna diskuterar, men när antalet blir för stort kan diskussionerna bli splittrade och ytliga. Det är också viktigt att det finns en maktbalans mellan intressegrupperna för att undvika att en grupp dominerar, viktiga perspektiv missas och/eller diskussioner avslutas i förtid. Om du väljer att iscensätta ditt problem i framtiden kan du hitta på intressegrupper som inte finns idag, till exempel för att jämna ut maktbalansen mellan grupperna eller tillföra perspektiv som är särskilt relevanta för undervisningsämnet. I min egen undervisning har jag ibland valt att låta två intressegrupper representera liknande perspektiv för att kunna få med perspektiv som är svårare att argumentera för; grupperna har då fått ett numerärt övertag i diskussionerna och maktbalansen har jämnats ut. När jag undervisar ingenjörsstudenter försöker jag också alltid inkludera intressegrupper som huvudsakligen fokuserar på social och global hållbarhet, då jag av erfarenhet vet att ingenjörsstudenter ofta känner sig mindre bekväma att representera dessa perspektiv (eftersom de inte har fătt mycket utbildning om det).

I min beskrivning av coronapandemin har jag valt intressegrupper som finns i verkligheten och som representerar olika typer av aktörer i samhället: Finansdepartementet (FD) representerar regeringen, Värdförbundet (VF) är en fackförening som representerar arbetstagare, Svenska resebyrå- och arrangörsföreningen (SRA) är en branschförening som representerar entreprenörer och arbetsgivare, Funktionsrätt Sverige (FR) är en intresseorganisation som representerar en socialt utsatt grupp och Fossil free Sverige (FFS) är en ideell rörelse som representerar framtida generationer, djur och natur. Ofta bifogar jag en kort beskrivning av varje intressegrupp för att ytterligare underlätta för studenterna att komma igång.

En viktig utgångspunkt i lärande för hållbar utveckling är att ekologiska, ekonomiska och sociala perspektiv måste finnas med (Rieckmann, 20I2; UNESCO, 20I7). I coronapandemiexemplet är ekonomiska och sociala perspektiv självklara. SRA och Finansdepartementet tillför främst ekonomiska perspektiv: SRA har ett intresse av att minimera restriktioner för resor och arrangemang och att få ekonomiskt stöd från regeringen; Finansdepartementet har ett intresse av att stabilisera arbetsmarknaden och undvika 
en ekonomisk kollaps (bland annat genom att ge ekonomiskt stöd till resebranschen), men även att hushålla med ekonomiska resurser. Vårdförbundet och Funktionsrätt Sverige tillför främst sociala perspektiv. Vårdförbundet har ett intresse av att minska antalet patienter som behöver vårdas på sjukhus - vilket kräver starkare restriktioner i samhället, speciellt för riskgrupper. Funktionsrätt Sverige har också ett intresse av starkare restriktioner eftersom deras medlemmar ofta tillhör riskgrupper. De vill dock ha restriktioner som slår jämnt över befolkningen istället för att isolera riskgrupper. Det ekologiska perspektivet har varit mindre synligt i den offentliga debatten under pandemin, men har till exempel lyfts fram i diskussioner om pandemins effekter på klimatet. Fossil free Sverige tillför det perspektivet genom sitt engagemang för just klimatfrågor; de försöker använda pandemin för att påskynda samhällsomställningen mot att fasa ut användningen av fossila bränslen.

Istället för att inkludera en beskrivning av intressegrupper kan du välja att låta studenterna själva göra en intressentanalys och välja intressegrupper. Det ger fler möjligheter till lärande, men riskerar att leda till en obalanserad uppsättning intressegrupper som du kan behöva justera i efterhand. Dock är min erfarenhet att studenter ofta identifierar intressegrupper som liknar dem jag själv hade valt. Det är inte heller förvånande eftersom studenternas analys baseras på problembeskrivningen de får av mig — som är konstruerad så att den ska synliggöra de intressenter och perspektiv som jag tror är viktiga för att diskutera problemet.

3. Formulera bakgrundsinformation som behövs för att kunna diskutera problemet. En engagerad diskussion uppstår sällan ur tomma intet, det behövs ett konkret innehåll som skapar intresse och väcker känslor. Det är därför viktigt att inkludera bakgrundsinformation om problemet i problembeskrivningen. Om problemet är välbekant för studenterna behövs endast information som kan stimulera diskussion. I beskrivningen av coronapandemin har jag till exempel endast lagt in en kort beskrivning av hur viruset upptäcktes, vilka hälsoeffekter en infektion kan ge och hur regeringen har försökt minska smittspridningen och begränsa ekonomiska och sociala effekter av restriktioner. Om studenterna förväntas ha mindre kunskap om problemet kan du behöva inkludera mer detaljerad bakgrundsinformation för att de ska kunna diskutera problemet på ett meningsfullt sätt. När jag i min undervisning har missat detta har jag ofta upplevt att studenter blivit osäkra och frustrerade över att behöva argumentera för något de inte hade kunskap om. Du kan dock även ge studenterna i uppgift att själva ta reda på den information de behöver för att förstå problemet och intressegruppernas perspektiv. Då får de även träna att bedöma vilken information de behöver för att kunna arbeta med problemet — en mycket viktig förmåga i lärande för hållbar utveckling. Sist men inte minst kan du be studenterna intervjua personer som kan antas representera intressegrupperna. Det personliga mötet kan hjälpa studenterna att inte bara ta till sig fakta om intressenterna, utan även en empatisk förståelse för hur problemet kan upplevas utifrån olika perspektiv.

4. Markera att det finns problem. Många studenter har en stark drivkraft att bidra till att hitta lösningar på svåra samhällsutmaningar. Den drivkraften kan du använda för att skapa engagemang i undervisning om och med wicked problems genom att tydligt poängtera att den situation du beskriver är djupt problematisk. I beskrivningen av coronapandemin har jag använt ord och uttryck som mer eller mindre är synonyma med "problem" (t.ex. "mycket ansträngd situation", "kris", "negativa effekter", "drabbades särskilt hårt", "kostsamma", "sämre", "oro"), men även ord som ofta uppfattas som negativa (t.ex. "sjukdom", "pandemi", "dödsfall", "arbetslöshet", "fattigdom"). I figur I är dessa ord markerade med röd text.

5. Bygg in alla intressegruppers perspektiv i problembeskrivningen. Förutom att intressegrupperna introduceras behöver deras perspektiv vara tydligt synbara i problembeskrivningen. 
Synligheten ger legitimitet till grupperna och skapar förutsättningar för att deras perspektiv ska upplevas som relevanta att diskutera. I beskrivningen av coronapandemin synliggörs intressegrupperna genom att explicit nämna "regeringen" (Finansdepartementet); "vården" (Vårdförbundet); "besöksnäringen" (SRA); "underliggande sjukdomar" och "barn med funktionsvariationer" (Funktionsrätt Sverige); samt "ses av vissa som en möjlighet att bromsa den globala uppvärmningen" (Fossil free Sverige). I figur I är dessa ord och uttryck markerade med blå text.

6. Bygg in minst ett argument för varje intressegrupp. Studenter kan lätt bli överväldigade av komplexiteten i wicked problems och av att inte ha expertkunskap om problemet de ska diskutera (Lönngren et al., 20I7, 20I9). Det är inget problem i sig eftersom ett viktigt mål med undervisning om och med wicked problems är att studenter ska tränas i att hantera hållbarhetsproblem, även när det råder stor osäkerhet och komplexitet (Lönngren, 2017; Lönngren \& Svanström, 20I5). Samtidigt är det viktigt att studenterna inte ger upp innan de ens har börjat (Lönngren et al., 2017). Ett sätt att hjälpa studenter komma igång är att inkludera något argument för varje intressegrupp i problembeskrivningen. Dessa argument kan ge studenterna en första ingång till att diskutera olika perspektiv på problemet och förstå hur de olika intressegrupperna kan tänkas förhålla sig till problemet och till varandra. I figur I har jag markerat dessa argument med kursivstil följt av [intressegruppernas akronym $i$ hakparenteser]. Jag har inkluderat ett argument var för intressegrupperna Finansdepartementet [FD], Vårdförbundet [VF], SRA [SRA] och Fossil free Sverige [FFS]. Funktionsrätt Sverige är den intressegrupp som har svagast koppling till problemet och där jag förväntar mig att studenter ska ha svårast att hitta bra argument. För att stärka gruppens position gentemot de andra grupperna har jag inkluderat två argument för denna grupp [FRI, FR2] i problembeskrivningen.

7. Markera intressekonflikter. En del studentgrupper, speciellt bland ingenjörsstudenter, har en tendens att försöka uppnå konsensus så fort som möjligt för att komma fram till en lösning (Lönngren, 20I7). Ur ett lärandeperspektiv kan det vara problematiskt då ett viktigt mål med undervisningen är att studenterna ska lära sig hantera problem som inte har enkla lösningar och hantera intresse- och värdekonflikter (Rieckmann, 20I2; UNESCO, 20I7; Wiek et al., 20II). Det är därför viktigt att intressekonflikter lyfts fram i problembeskrivningen. Det handlar inte om att alla sådana konflikter behöver beskrivas explicit, men det är lättare för studenterna att komma igång med diskussionerna om någon eller några konflikter är lätta att uppfatta. I beskrivningen av coronapandemin markeras intressekonflikter framförallt med ordet "samtidigt", men även ordet "möjlighet" används — vilket här står i kontrast mot övriga delar av beskrivningen som tydligt fokuserar på problem. I figur I markeras dessa ord med lila text.

8. Formulera kontext, mål och mottagare. Många studenter blir oroliga när de inte förstår vad de förväntas göra och uppnå, speciellt när de ska arbeta med problem som saknar entydiga lösningar (Lönngren et al., 2010). Oron är dels en produkt av att studenterna har lärt sig att deras prestationer ständigt mäts och betygsätts, dels av att många (ingenjörs)studenter inte har tränats i att hantera wicked problems i tillräcklig utsträckning. Oron är inte produktiv för lärandet (Cilliers et al., 20Io); den kan leda till att studenter inte vågar diskutera problemet på ett meningsfullt sätt då de är alltför upptagna med att försöka förstå vad som är "rätt svar". Det är därför viktigt att hjälpa studenterna hantera sin oro och förstå vad de ska göra - dock utan att minska komplexiteten i själva problemet. Du kan till exempel formulera en konkret kontext, ett mål och en mottagare för uppgiften: Vem är uppdragsgivaren och 


\section{Johanna Lönngren}

mottagaren? Hur ska slutprodukten se ut? Och under vilka förutsättningar ska slutprodukten tas fram? I coronapandemiexemplet är mottagaren "Folkhälsomyndigheten", uppgiften att "diskutera", slutprodukten att "försöka enas om vilka restriktioner, rekommendationer och stödpaket som bör gälla under jul och nyår 2020" och kontexten ett möte till vilket Folkhälsomyndigheten "bjuder [...] in en rad intressenter", det vill säga, intressegrupperna (markeras med fetstil i figur I). Observera att målet formuleras på ett sätt som indikerar att det kanske inte är möjligt att enas och att det därför inte är ett misslyckande om studenterna inte uppnår enighet (de ska "försöka"). Detta är viktigt för att minska studenternas oro.

Sist men inte minst: undvik att formulera målet med uppgiften som en ja/nej-fråga, då detta kan leda till att en del av komplexiteten i uppgiften går förlorad — studenterna kan uppfatta ett sådant mål som att rätt svar är "ja" eller "nej" och att det inte finns något mer att diskutera när de har enats om vilket av de givna alternativen som är "det rätta" (Dobson \& Tomkinson, 20Io). Av samma anledning bör du undvika att ge studenterna en uppsättning färdiga lösningar att välja mellan. Resultatet av diskussionerna måste hållas öppet för att studenterna ska få möjlighet att diskutera problemet på ett förutsättningslöst sätt och komma fram till egna "lösningar".

\section{AVSLUTANDE RÅD}

Jag beskrivit hur jag gör när jag tar fram problembeskrivningar för undervisning om och med wicked problems. Jag har presenterat åtta designprinciper, som jag har utvecklat under mer än tio års forskning och undervisning, och illustrerat dem med hjälp av ett aktuellt exempel: en beskrivning av coronaviruspandemin som ett wicked problem. Det är viktigt att komma ihåg att en beskrivning inte behöver bli perfekt, det kan den inte heller. Det viktigaste är att den kan väcka engagemang och diskussioner om normer och värderingar, om vilket samhälle vi vill leva i och om hur vi, tillsammans, kan skapa ett sådant samhälle.

\section{FÖRFATTARPRESENTATION}

Johanna Lönngren är universitetslektor vi Institutionen för naturvetenskapernas och matematikens didaktik vid Umeå universitet. Hennes forskning fokuserar på lärande för hållbar utveckling i ingenjörsutbildningar. För närvarande undersöker hon vilken roll känslor spelar i det lärandet. Johanna har lång erfarenhet av att undervisa ingenjörsstudenter om hållbar utveckling och hon undervisar även i högskolepedagogik fokuserad på lärande för hållbar utveckling. På https://wickedproblemsteaching.wordpress.com/ har Johanna samlat fler exempel på problembeskrivningar. Där finns även en beskrivning av intressegrupperna för coronavirusexemplet. Kontakta gärna Johanna om du har egna exempel som du vill dela med dig av.

\section{REFERENSER}

Brundiers, K., Wiek, A. \& Redman, L. (2010). Real-world learning opportunities in sustainability: From classroom into the real world. International Journal of Sustainability in Higher Education, 11(4), $308-324$.

Cilliers, F. J., Schuwirth, L. W., Adendorff, H. J., Herman, N. \& van der Vleuten, C. P. (2010). The mechanism of impact of summative assessment on medical students' learning. Advances in Health Science Education, 15, 695-715.

Dobson, H. E. \& Tomkinson, C. B. (2010, September 19). Creating Sustainable Development Change Agents through Problem Based Learning: From rearranging the deckchairs on the Titanic to inciting social revolution - where should student PBL projects be pitched? Engineering Education in Sustainable Development, Gothenburg, Sweden. 
Grint, K. (2005). Problems, problems, problems: The social construction of 'leadership.' Human Relations, 58(11), 1467-1494.

Ison, R. L., Collins, K. B. \& Wallis, P. J. (2015). Institutionalising social learning: Towards systemic and adaptive governance. Environmental Science and Policy, 53, 105-117.

Lönngren, J. (2017). Wicked Problems in Engineering Education: Preparing Future Engineers to Work for Sustainability. Chalmers University of Technology.

Lönngren, J., Ahrens, A., Deppert, K., Hammarin, G. \& Nilsson, E. (2010, September 19). Sustainable Development in Nano-Perspectives - An Innovative Student Initiative. Engineering Education in Sustainable Development, Gothenburg, Sweden.

Lönngren, J. \& Svanström, M. (2015). Assessing “Wicked Sustainability Problem"-Literacy in Engineering Education. 122nd ASEE Annual Conference \& Exhibition, Seattle.

Lönngren, J., Ingerman, Å. \& Svanström, M. (2017). Avoid, Control, Succumb, or Balance: Engineering Students' Approaches to a Wicked Sustainability Problem. Research in Science Education, 47, 805-831.

Lönngren, J., Adawi, T. \& Svanström, M. (2019). Scaffolding strategies in a rubric-based intervention to promote engineering students' ability to address wicked problems. European Journal of Engineering Education, 44(1-2), 196-221.

Lönngren, J. \& Van Poeck, K. (2020). Wicked problems: A mapping review of the literature. International Journal of Sustainability \& World Ecology.

Molderez, I. \& Fonseca, E. (2018). The efficacy of real-world experiences and service learning for fostering competences for sustainable development in higher education. Journal of Cleaner Production, 172, 4397-4410.

Rieckmann, M. (2012). Future-oriented higher education: Which key competencies should be fostered through university teaching and learning? Futures, 44(2), 127-135.

Rittel, H. W. \& Webber, M. W. (1973). Dilemmas in a General Theory of Planning. Policy Sciences, 4, $155-169$.

UNESCO. (2017). Education for Sustainable Development Goals: Learning Objectives. UNESCO. http:// unesdoc.unesco.org/images/0024/002474/247444e.pdf

Wiek, A., Withycombe, L. \& Redman, L. (2011). Key competencies in sustainability: A reference framework for academic program development. Integrated Research System for Sustainability Science, 6, 203-218. 